\title{
22
}

\section{Honduran Imhoff Tanks: Potentials and Pitfalls}

\author{
Anne Mikelonis, Ari Herrera, E. Eric Adams and Matthew Hodge
}

An Imhoff tank is a structure originally designed to provide primary wastewater treatment. It is a sedimentation tank with a steeply sloped floor resting above a sludge digester. During the 1930s, Imhoff tanks represented 50\% of all wastewater treatment facilities in the United States. The majority of Imhoff tanks within the U.S. have since been abandoned or modified to adapt to changing treatment objectives and regulations. However, within the Central American country of Honduras they continue to represent a significant portion of the wastewater treatment infrastructure and are routinely designed and constructed where populations are small and terrain is limited.

In Honduras, stormwater inflow and infiltration into wastewater treatment systems pose significant challenges. The drainage flows in urban areas mix with raw sewage creating dilute, but large volumes of, wastewater that requires treatment. Imhoff tanks in Honduras use design parameters more suitable for dryer regions of the world that do not experience such consequences of stormwater. These tanks are therefore currently not successful in providing treatment to regulated levels.

Since 2006, the authors have researched improved maintenance and operation of Imhoff tanks in Honduras. The work includes, but is not limited to, monitoring wastewater flow rates, wastewater quality testing, improving gate and baffle designs, and bench-scale and pilot testing the use of solid aluminum sulfate as a coagulant for use in chemically enhanced primary treatment (CEPT) within the tanks. In addition to this detailed work, this chapter also presents the

Mikelonis, A., A. Herrera, E. Adams and M. Hodge. 2010. "Honduran Imhoff Tanks: Potentials and Pitfalls." Journal of Water Management Modeling R236-22. doi: 10.14796/JWMM.R236-22.

(C) CHI 2010 www.chijournal.org ISSN: 2292-6062 (Formerly in Dynamic Modeling of Urban Water Systems. ISBN: 978-0-9808853-3-0) 
authors' survey of several Honduran communities with Imhoff tanks in order to assess common design features and system failures.

This chapter contains a brief background of the status of wastewater treatment and Imhoff tanks within Honduras. It also succinctly discusses the governing technical considerations involved with treating wastewater in an Imhoff tank. It identifies some of the challenges that Honduran municipalities face while maintaining these systems, and highlights some of the low cost solutions implemented in other locations. Through awareness of these issues, stormwater management plans and easy-to-use design models could be developed. In-depth technical details on project aspects such as site specific flows and loads and CEPT may be found in Herrera (2007), Mikelonis (2008) and Hodge (2008).

\subsection{Sanitation in Honduras}

In 2004, SERNA (Honduras's environmental protection agency) estimated that approximately $68 \%$ Hondurans had access to some form of sanitation services. For approximately $25 \%$ coverage is through domestic connections (such as flush toilets) and for $43 \%$ coverage is via latrines. Within urban areas, it is estimated that $88 \%$ have coverage. However sewage transport should not be confused with treatment. It is estimated that only about $10 \%$ collected wastewater is actually treated (SERNA, 2005).

Additionally, according to SERNA, the country operates 41 wastewater treatment systems including 18 Imhoff tanks, 18 waste stabilization ponds, and 5 using other technologies (SERNA, 2005). This last category includes the capital, Tegucigalpa, which has an activated sludge treatment plant. However, in Honduras different sources report statistics that do not necessarily agree. SANAA is the national water and sewerage utility in Honduras and has historically engineered the majority of the country's water and wastewater infrastructure. A 2000 survey of wastewater treatment facilities in Honduras by SANAA includes 51 locations. More recently, a high level SANAA engineer also mentioned that there are 96 packaged treatment plants (activated sludge) throughout the country. Two-thirds were installed by a local Honduran supplier, CALIX (P. Ortiz, personal communication, January 8, 2009). Based on these statistics it is clear that any improvements made to Imhoff tanks will play a significant role in improving the existing wastewater infrastructure within the country.

Despite a meager percentage of total collected wastewater undergoing treatment within the country, the government has set high treatment goals. Ta- 
ble 22.1 lists the maximum permitted values of parameters under national effluent regulations. In reality, there is little monitoring or penalty imposed on systems that do not conform.

Table 22.1 Honduras wastewater regulations (Secretaria, 1997).

\begin{tabular}{lc}
\hline \multicolumn{2}{c}{ Effluent Regulations } \\
Parameter & Max Permitted \\
\hline BOD $_{5}$ & $50.0 \mathrm{mg} / \mathrm{L}$ \\
COD & $200.0 \mathrm{mg} / \mathrm{L}$ \\
Total Kjeldahl Nitrogen & $30.0 \mathrm{mg} / \mathrm{L}$ \\
Ammonia as Nitrogen & $20 \mathrm{mg} / \mathrm{L}$ \\
Total Phosphorous & $5.0 \mathrm{mg} / \mathrm{L}$ \\
pH & $6.0-9.0$ \\
Sulfates & $400.0 \mathrm{mg} / \mathrm{L}$ \\
Aluminum & $2.00 \mathrm{mg} / \mathrm{L}$ \\
Settable Solids & $1.0 \mathrm{~mL} / \mathrm{L} / \mathrm{h}$ \\
Suspended Solids & $100.0 \mathrm{mg} / \mathrm{L}$ \\
Total Fecal Coliforms & $5000 / 100 \mathrm{~mL}$ \\
\hline
\end{tabular}

Interviews during January 2008 with engineers at SANAA revealed strong preferences on their part for the use of waste stabilization ponds wherever possible. Imhoff tanks were viewed as a technology of the 1990s whereas the past decade has witnessed the successful implantation of numerous ponds in Honduras. The engineers claim that the ponds are able to provide long enough residence times to kill pathogens, and that they store more sludge and therefore do not need to be cleaned as often as Imhoff tanks. In Honduras, the majority of rivers provide plenty of natural reaeration so factors such as biochemical oxygen demand (BOD) are not as crucial an issue as pathogen removal (P. Ortiz, personal communication, January 23, 2008).

Despite this preference, Imhoff tanks are not a thing of the past within Honduras. The systems continue to be designed, planned and constructed by both local government and international aid agencies for small populations (approximately 5000 to 10000 residents) with limited flat land for waste stabilization ponds. Much of the mountainous Honduran terrain lacks electricity and communities have a shortage of skilled engineers. In these situations, an Imhoff tank potentially provides an appropriate gravity-driven solution to primary treatment and sludge disposal. At the same time, if improperly maintained they may create an even more harmful sanitary condition.

\subsection{Imhoff Tanks}

Karl Imhoff invented and patented the Imhoff tank in Germany in 1906 (Her- 
rera, 2006). An Imhoff tank is a structure designed to provide primary wastewater treatment. It is a sedimentation tank with a steeply sloped conical floor resting above a sludge digester. Imhoff tanks are normally constructed with a minimum of two tanks in parallel. This allows the operators to clean one tank without shutting down the entire system.

The tanks function on the principle that larger particles of the total suspended solids (TSS) enter the sedimentation chamber and fall through a small opening into the sludge storage and digestion chamber. In turn this removal of solids also decreases the oxygen demand of the wastewater. The removed solids are then anaerobically stabilized in the sludge storage chamber through natural biochemical and microbiological reactions until the chamber fills up. It is possible to empty the sludge storage chamber by gravity using valves located at the bottom of the tanks.

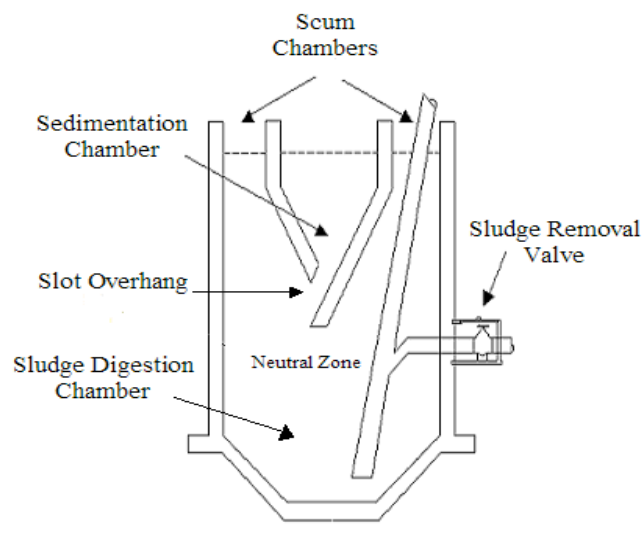

Figure 22.1 Imhoff tank schematic (modified from Mikelonis, 2008).

\subsubsection{Mechanics}

Flow through the upper sedimentation chamber can be achieved by longitudinal horizontal flow, vertical flow (although rarely utilized) or radial flow. In some installations influent and effluent weirs distribute flow uniformly throughout the sedimentation chamber (Metcalf, 1935). The sedimentation chamber's depth must be shallow enough so as not to inhibit vertical distribution of flow but also deep enough so that the slow-motion settling zone is not encroached. In 
order to avoid solids accumulation and decomposition in the sedimentation chamber, Metcalf recommended that a squeegee be used to periodically clean the sides of the sedimentation chamber.

The sludge chamber includes a sludge-storage space and a neutral zone between the storage area and the slot entrance into the sedimentation chamber. In order to utilize the entire tank and avoid an uneven distribution of settled solids Metcalf recommended to reverse the flow every month. It is theoretically possible through employment of the force of gravity to empty the sludge storage chamber by using valves located at the bottom of the tanks. Sludge is removed by flowing through pipes, which extend a short distance inside the hopper. Gas produced within the sludge storage chamber is released through vents into a scum space that must be skimmed every few days to remove floating particles of digested sludge. Care must be paid to keep the water level in the system constant in order to avoid the exchange of contents between the sedimentation and digestion chambers. Differences of hydrostatic pressure can result in surges of sludge up through the slots (Metcalf, 1935).

Expected treatment levels from a properly maintained Imhoff tank are the same as those for isolated sedimentation tanks without a sludge digester. Typically, an Imhoff tank will provide a TSS removal rate of $20 \%$ to $70 \%$ and $10 \%$ to $40 \%$ for $\mathrm{BOD}_{5}$ (Reynolds and Richards, 1996). The actual removal rate for a specific tank will be a function of influent water quality and tank detention time. In the absence of any additional treatment, the sedimentation process will not yield substantial reductions in other important water quality indicators such as total coliform counts or nutrient loading from phosphorus and nitrogen.

The solids that settle into the bottom storage chamber of the Imhoff tank are termed sludge and undergo anaerobic digestion. Anaerobic digestion is a four stage process of hydrolysis, acidogenesis, acetogenesis, and methanogenesis that causes considerable change to the physical, chemical and biological properties of the sludge (Mara, 2004). The end result of successful anaerobic digestion is stable solids that will not degrade and from which water will easily separate (Reynolds and Richards, 1996). After the digestion process is complete, the sludge may be removed from the Imhoff tank and be dewatered on a sludge drying bed or by other equivalent means.

\subsubsection{Design Criteria}

Table 22.2 includes updated design criteria that were adapted from the third edition of Wastewater Engineering: Treatment, Disposal, and Reuse by Metcalf and Eddy, Inc. (Tchobanoglous and Burton, 1991). 
Table 22.2 Design criteria for unheated Imhoff tanks.

\begin{tabular}{|c|c|c|}
\hline \multirow[b]{2}{*}{ Design Parameter } & \multicolumn{2}{|c|}{ Value } \\
\hline & Range & Typical \\
\hline \multicolumn{3}{|l|}{ Settling Compartment } \\
\hline Overflow rate, peak hour $\mathrm{m}^{3} / \mathrm{m}^{2} / \mathrm{h}$ & $1-1.75$ & 1.36 \\
\hline Detention time, $\mathrm{h}$ & $2-4$ & 3 \\
\hline Length to width ratio & $2: 1-5: 1$ & $3: 1$ \\
\hline Slope of settling compartment ratio & $1.25: 1-1.75: 1$ & $1.5: 1$ \\
\hline Slope opening, $\mathrm{cm}$ & $15-30$ & 25 \\
\hline Slot overhang, $\mathrm{cm}$ & $15-30$ & 25 \\
\hline \multicolumn{3}{|l|}{ Scum baffle } \\
\hline Below surface, $\mathrm{cm}$ & $25-41$ & 30 \\
\hline Above surface, $\mathrm{cm}$ & 31 & 30 \\
\hline Freeboard, cm & $45-60$ & 60 \\
\hline \multicolumn{3}{|l|}{ Gas vent area } \\
\hline Surface area, $\%$ total surface area & $15-30$ & 20 \\
\hline Width of opening, $\mathrm{cm}^{1}$ & $45-75$ & 60 \\
\hline \multicolumn{3}{|l|}{ Digestion section } \\
\hline Volume (unheated), storage capacity, $\mathrm{m}^{3} /$ capita & & 6 months sludge \\
\hline Volume, $\mathrm{m}^{3} / 6$ month storage ${ }^{2}$ & $0.06-0.10$ & 0.07 \\
\hline Sludge withdrawal pipe, $\mathrm{cm}$ & $20-30$ & 25 \\
\hline Depth below slot to top of sludge, $\mathrm{m}$ & $0.30-0.90$ & 0.60 \\
\hline \multicolumn{3}{|l|}{ Tank depth } \\
\hline Water surface to tank bottom, $\mathrm{m}$ & $7-10$ & 9 \\
\hline
\end{tabular}

\subsubsection{Advantages}

Imhoff tanks remain a viable treatment option in certain developing communities for several reasons. An Imhoff tank is a low maintenance, low cost option in comparison to processes such as activated sludge treatment. Primary treatment through sedimentation offers the possibility of reducing the negative environmental and human health effects of untreated sewage to low enough levels that natural processes such as dilution and biodegradation can accomplish adequate remaining treatment. Of course, the effectiveness of these latter treatment modalities depends significantly on the natural assimilation capacity of receiving land and water bodies. Additionally, Imhoff tanks do not need the large amounts of flat land that waste stabilization ponds or constructed wetlands require. For example, based on the flows and loads in the central urban area of the Honduran community of Las Vegas, Santa Bárbara, the surface area required for an Imhoff tank is estimated at $110 \mathrm{~m}^{2}$ whereas the surface area required for a single maturation pond is $17640 \mathrm{~m}^{2}$ (Hodge,2008). In the moun- 
tainous terrain of Honduras this advantage is significant. Imhoff tanks also provide storage and gravity removal mechanisms for digested sludge that plain sedimentation basins do not. Further, with proper planning Imhoff tanks may later be coupled with applicable forms of secondary and tertiary treatment as needed and capital becomes available to a community for investment in the facilities required for such treatment.

\subsection{Imhoff Tanks in Honduras}

Figure 22.2 maps the known locations of all Imhoff tanks in Honduras. The majority of the Honduran population is located in the western portion of the country since the eastern side is a tropical rain forest. Imhoff tanks were surveyed by the authors in the following locations:

- Las Vegas, Santa Bárbara;

- Barrio Llano del Conejo, Santa Bárbara;

- Barrio Galeras, Santa Bárbara;

- Gualala, Santa Bárbara;

- Marcala, La Páz;

- Villa Linda Miller, Francisco Morazán; and

- Guaimaca, Francisco Morazán.

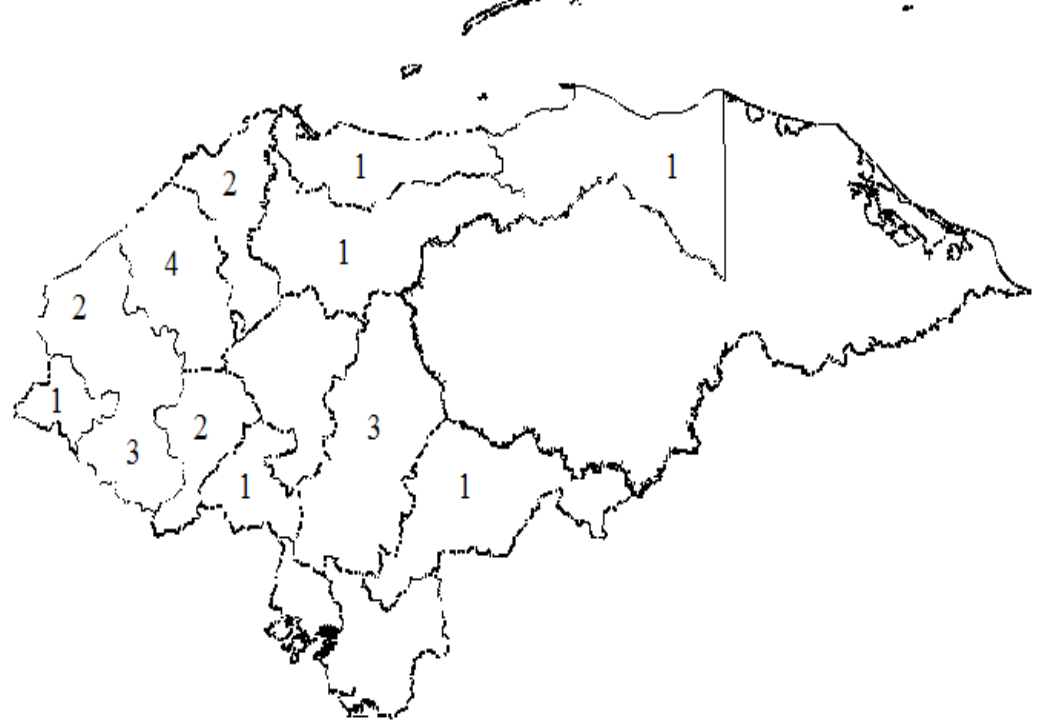

Figure 22.2 Distribution of Imhoff tanks throughout Honduras (Mikelonis, 2008). 


\subsubsection{Case Studies}

Surveys of these Imhoff tanks illuminated differences in designs that have a major impact on the practicality and sustainability of the systems. On one hand many are missing necessary items such as a means to measure flow, locations for sludge drying beds, control gates or baffles for properly distributing flow. Further, some have walls that leak or have collapsed. On the other hand, others are structurally sound and include all essential elements, plus include secondary treatment and plans for odor control. In order to demonstrate these potentials and pitfalls the community stories of Las Vegas and Villa Linda Miller are used as the main case studies.

\section{Las Vegas}

The Honduran municipality of Las Vegas uses two Imhoff tanks in parallel to treat wastewater produced by the city's urban center that has a population of approximately 3600 residents. These are shown in Figures 22.3 and 22.4 The existing structures were built in 1992 with capital funds from the Honduran Social Investment Fund (FHIS in Spanish) and are currently ineffective at treating the wastewater produced by residents. The tanks were originally designed to serve 4000 residents producing $250 \mathrm{~L} /$ person/d wastewater. Their construction was part of a program to create construction jobs in the area (J. Nuñez, personal communication, January 23, 2008).

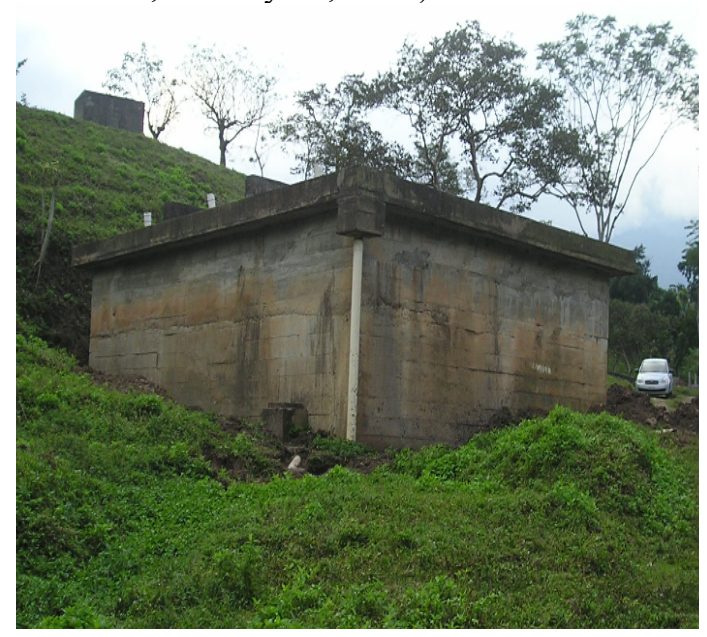

Figure 22.3 Las Vegas Imhoff tanks. 


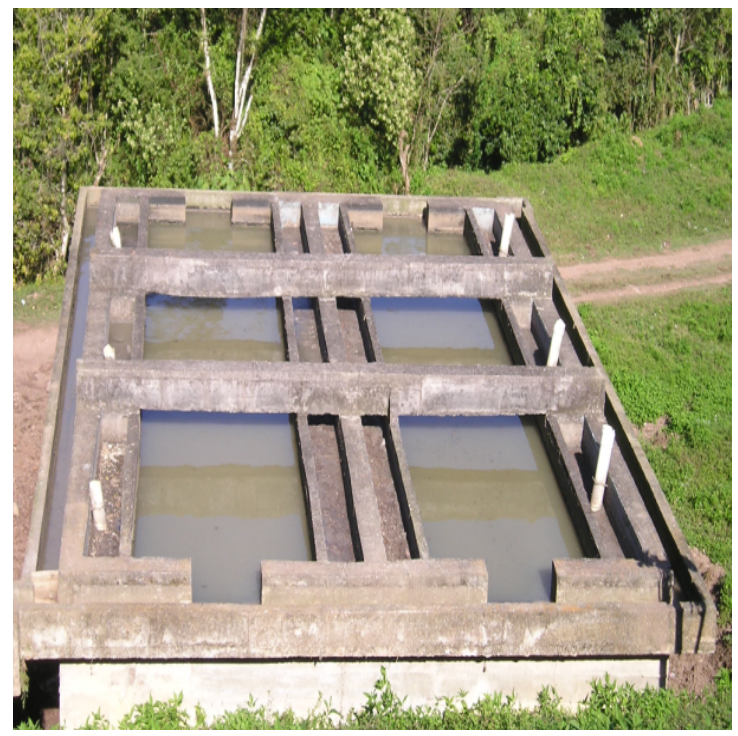

Figure 22.4 Top view of Las Vegas Imhoff tanks.

The Imhoff tanks in Las Vegas lack several key design features. There is no electricity at the site so without an influent flume or weir there is not an accurate or consistent way to measure flow. A lack of understanding of the incoming flows has lead to a drastic overloading of the system. Many locals depulp coffee in their homes (this involves leaving the tap running through the night). There are also a significant number of illegal connections and infiltration into the sewer pipes. Currently the system receives roughly $1000 \mathrm{~L} /$ person/d wastewater rather than the original design value of 250 . This results in a very low retention time and scouring of partially digested sludge. Fecal coliform levels increase in the tanks (Hodge, 2008).

The tanks also lack flow gates and baffles. A lack of flow gates results in a portion of the flow bypassing the sedimentation basins and thus exiting the system after a very short retention time. The lack of baffles results in an uneven distribution of flow across the sedimentation basins. An uneven distribution of flow across the basins means that the sludge digestion chamber is not being fully utilized. The introduction of wooden gates coupled with bags of sand effectively remedies this situation using inexpensive local materials, as shown in Figure 22.5. Additionally inlet baffles can be constructed out of wood by drilling a series of holes. Implementation of these options is simple, the real challenge is ensuring that the materials are not removed or stolen. 

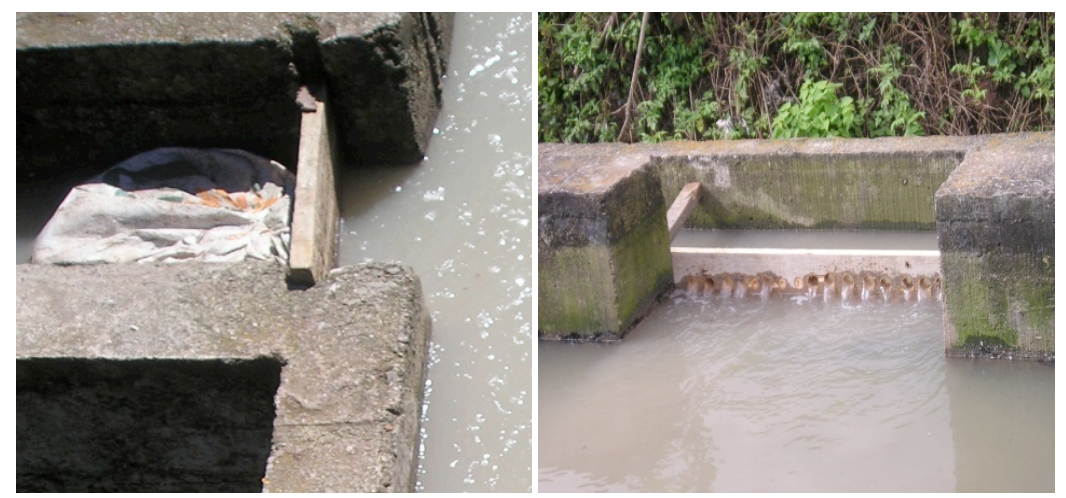

Figure 22.5 Wooden flow gates with sand bags and wooden inlet baffle.

The Imhoff tanks in Las Vegas are in good structural condition. After many years of neglecting sludge removal the solids were removed during December 2007 and buried next to the system (because Las Vegas lacks a sludge drying bed). The local government is very enthusiastic about improving their wastewater treatment system and supportive in receiving outside suggestions regarding how to improve the tanks.

\section{Villa Linda Miller}

The Imhoff tanks in Villa Linda Miller, shown in Figure 22.6, are an example of a well thought out design. One reason for this is that they were constructed more recently, in 2000 - post Hurricane Mitch, which devastated much of the infrastructure in Honduras. The system consists of two Imhoff Tanks in parallel for primary treatment, an upflow reactor for a secondary anaerobic system, and finally a sludge drying bed. Originally the system was designed to capture and treat odors with the help of a natural biofilter. Unfortunately, that part of the system was never fully completed.

Odor control is a major challenge in properly maintaining Imhoff tanks especially in areas where residences are downwind of the system. The Villa Linda Miller system attempts to address this issue with several different features. Concrete lips are provided on top of the sedimentation chambers with the idea of creating an interstitial space between the wastewater level in the sedimentation chamber and the concrete leads to allow foul odors from the system to accumulate in this area. In the interstitial space there are openings to allow 4 in. $(100 \mathrm{~mm})$ PVC pipes to collect the odors from both tanks and force them into a biofilter box constructed of concrete and brick. At the bottom of this biofilter 
box, the incoming PVC pipe is perforated in order to allow for even air flow distribution. The concept is that you could place wood chips or orange peels on top of the perforated pipe and thus be able to treat the odor.

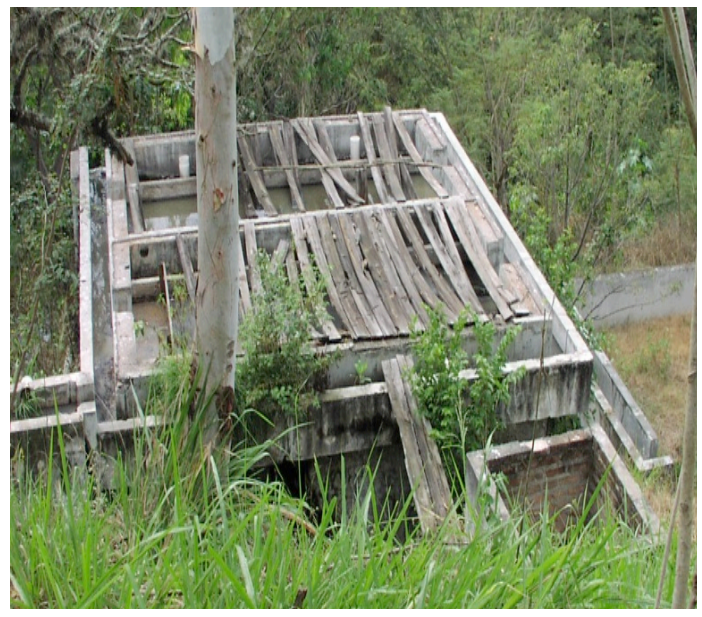

Figure 22.6 Villa Linda Miller Imhoff tanks.

There are also some other useful features in Villa Linda Miller. Unlike in Las Vegas, the influent channel leading into the Imhoff tank has a free fall vnotch weir to measure flow into the system, shown in Figure 22.7. The tanks are also located at a higher elevation than the sludge drying bed, which is connected to the sludge removal valves from the tank through PVC pipe. This allows for gravity sludge removal.

From the Imhoff tank, the effluent travels into a secondary anaerobic tank that contains different size of media (gravel). The anaerobic tank was designed in a way that backwash is accomplished by allowing the tank to fill up, keeping the influent from coming into the tank through a bypass system, and finally opening a valve at the bottom of the tank to allow all the water in the tank to drain, thus washing the media.

It is important to take a moment and note that despite robust engineering, social and political issues are the major reason these systems fall into disrepair. Villa Linda Miller's system was paid for by an international development agency, the local operator was trained by a SANAA engineer, and an aid agency sponsored two years of the operator's salary. The capital cost for this system was roughly US\$213 000 while the annual operating cost was only about $\$ 2000$, or about $1 \%$ of the total capital cost. For the 160 homes in the 
service area this only amounts to one dollar a month for sanitation services (less than the cost of a calling card or several bottles of Coke). Still, since there is not a culture of paying for treatment, by 2003 this system lacked an operator and proper maintenance.

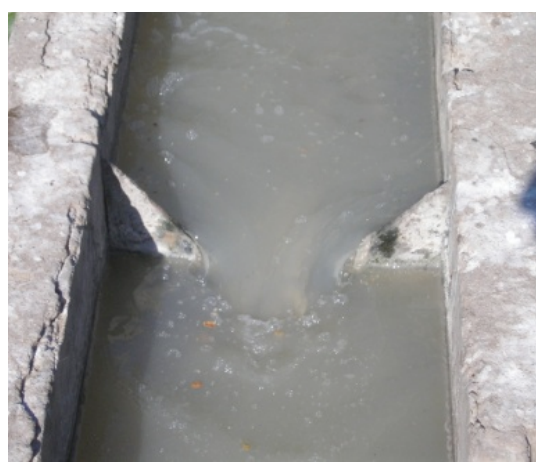

Figure 22.7 Example of an Imhoff tank free fall v-notch weir.

\section{Additional Honduran Imhoff tanks}

The remainder of the communities surveyed by the authors contained a combination of completely unsalvageable structures and structures ripe for rehabilitation. For example, the Marcala Imhoff tanks (Figure 22.8) are a massive below grade structure. The system is packed full of solids, which have even overflowed into boxes that house the sludge valves.

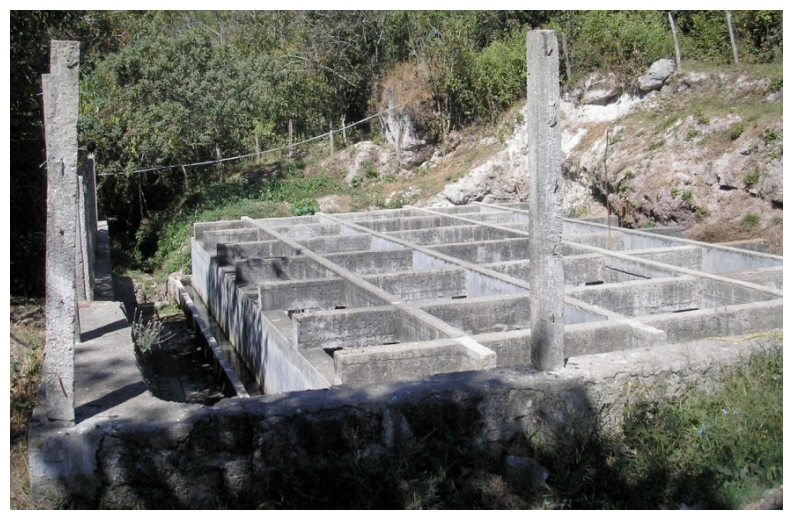

Figure 22.8 Marcala Imhoff tanks. 
If the solids were to be removed this system could be rehabilitated. On the other hand, systems like those in Barrio El Llano del Conejo, Santa Bárbara, were improperly constructed (Figure 22.9). The sloped walls of the sedimentation chambers were never completed. This has essentially rendered the system into an uncovered septic tank that does not receive maintenance. A sludge drying bed does not exist and the effluent is discharged into a shallow creek.

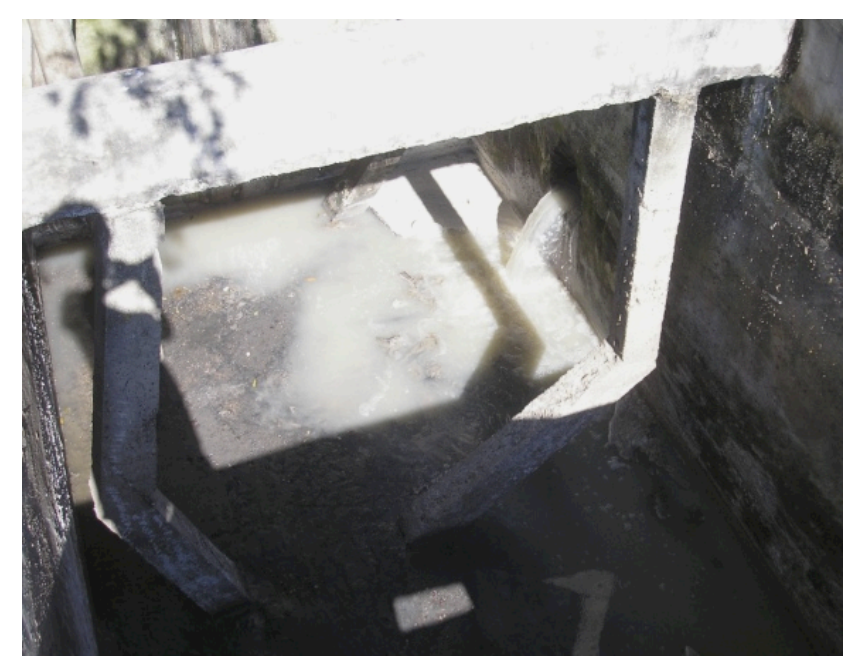

Figure 22.9 Incomplete sedimentation chamber in Barrio El Llano del Conejo.

Overall, the sites visited by the authors indicate numerous potentials and pitfalls. Many systems can and should be rehabilitated before investing in new infrastructure while at other sites, starting from scratch is probably the most reliable solution. For those with rehabilitation potential, before all else drying beds or other methods of appropriate sludge disposal should be designed. Then the sludge should actually be removed at each site on a regular schedule. If flows and loads warrant system expansion, that option should only be explored after a period of proper maintenance and minor modifications in order to get the existing Imhoff tanks into an optimum working condition. From the authors' experience, working closely with the municipality of Las Vegas, the local mayors and engineers were initially not only unaware of how an Imhoff tank functions and how to maintain it, but were also unaware that many of the solutions are not expensive. 


\subsection{Recommendations}

In the last ten years many Imhoff tanks in Honduras have been neglected due to various reasons such as lack of funds, damage during hurricanes, and constant changeover and inexperience in the local governments. The fact that it only takes approximately $5 \mathrm{~h}$ to drive from the northern portion of the country to the southern portion provides an opportunity for much knowledge sharing between the communities.

There is a tremendous need for a team of Honduran technicians to visit all of the existing systems and provide training as well as resources for the rehabilitation, operation and maintenance of Imhoff tanks. If a maintenance system of skilled technical professionals could be established much like the Circuit Rider programs provided by the Rural Water Associations in the United States there is great potential for improvements to be implemented.

Numerous opportunities exists to better understand the effects of stormwater on Imhoff tanks in Honduras. Quantification of inflows and infiltration during wet weather events could lead to drastic system design changes. Alternatively, implementation of stormwater management plans could divert some of the flows and thus increase the efficacy of the system as a whole. While modeling storm events positioning of flow distribution baffles and control gates within the tank should be varied in order to determine ideal placement.

Any work that takes place must be in coordination and cooperation with the agencies and people of the sanitation sector within Honduras. This way the benefit is mutual to those involved in international development work and the local people. Missions get to learn what are the perceived problems by the locals as well as to what they are planning on doing, and most importantly the areas where help is needed are identified, thus making it a lot easier for any group, individual or organization to see how they can become part of the solution, and resulting in a concentrated effort that maximizes the use of resources and gives sustainability a real chance.

\section{References}

Herrera, A. (2006). Rehabilitation of the Imhoff tank treatment plant in Las Vegas, Santa Barbara, Honduras, Central America. Unpublished Thesis, Department of Civil, Architectural, and Environmental Engineering, University of Texas at Austin. Austin, TX.

Hodge, M. (2008). Wastewater treatment in Las Vegas, Santa Barbara, Honduras. Masters of Engineering Thesis, Department of Civil and Environmental Engineering, Massachusetts Institute of Technology, Cambridge, MA. 
Mara, D. D. (2004). Domestic wastewater treatment in developing countries. London ; Sterling, VA: Earthscan Publications.

Metcalf, L. and Eddy, H. (1935). Imhoff tanks. In American sewerage practice (386-415). New York: McGraw Hill.

Mikelonis, A. (2008) Chemically Enhanced Primary Treatment of Wastewater in Honduran Imhoff tanks. Masters of Engineering Thesis, Department of Civil and Environmental Engineering, Massachusetts Institute of Technology, Cambridge, MA.

Reynolds, T. and Richards, P. (1996). Unit operations and process in environmental engineering. Boston: PWS Publishing Company.

Secretaría de Salud (1997). Normas téchnicas de las descarga de aguas residuales a cuerpos receptores y alcantarillado sanitario. Retrieved February, 2008 from http://www.ersaps.gob.hn/NR/rdonlyres/9D578951-ECC7-4FFD-B4C6F58A232750C9/817/NormasTecnicasDescargasAguasResiduales.pdf.

SERNA (2005). GEO Honduras: informe del estado y perspectivas del ambiente Retrieved November, 2007 from http://www.serna.gob.hn/Index/Principal/Documentos/GEO_Honduras_2005.pdf

Tchobanoglous, G. and Burton, F. (1991). Wastewater engineering: Treatment, disposal, and reuse. New York: McGraw-Hill. 